\title{
〔シンポジウム：生化学検査の標準化と測定の高感度化〕
}

\section{Lp (a)測定の標準化と疾患における意義}

\author{
久保野勝男 $* * * *$ 櫻林郁之介***
}

\begin{abstract}
SUMMARY
In order to standardize the lipoprotein(a) $[\mathrm{Lp}(\mathrm{a})]$ measurement, the International Federation of Clinical Chemistry Working Group on Lp(a) (IFCC Lp(a) WG) and the Japan Society of Clinical Pathology Working Group on $\mathrm{Lp}(\mathrm{a})$ Standardization were established in 1995, 1994, respectively. In the activities on IFCC Lp(a) WG, eight proposed reference materials (PRM) were compared for their analytical performance, commutable properties, method harmonization, and selected PRM-2B (Behring) as the most suitable PRM. In the next phase of the IFCC Lp(a) WG, a value transfer protocol will be used to transfer a $L p(a)$ value from the PRM-2 for $L p$ (a) to manufactures' master calibrators, and WG will submit the results to WHO. On the other hand, it is recommended that the $\mathrm{Lp}$ (a) protein concentration should be expressed in molar units for more accurate $\mathrm{Lp}(\mathrm{a})$ measurement. So it will be expected that new clinical estimation is investigated.
\end{abstract}

Key words: lipoprotein(a), standardization, proposed reference material, primary standard, harmonization.

はじめに

Lipoprotein(a) [以下 Lp(a)] は，1963 年ノルウ エーの遺伝学者 Berg らによって低比重リポタンパク （LDL）の遺伝性変異として報告されたりポ蛋白であ $\eta^{11)}, 1987$ 年には Maclean らがその cDNA の構造解 析をしている2). Lp (a) の特異蛋白部分である apo (a) 構造がプラスミノゲンと類似することなどから，動脈 硬化性疾患との関連性についてこれまで多くの研究が 重ねられてきた ${ }^{3,4}$. Lp (a)の測定には ELISA や自動 分析装置を使った免疫比濁法（TIA や LTIA）など の定量的測定法が日常検查に多く用いられている. $\mathrm{Lp}(\mathrm{a})$ 值は各試薬メーカーが独自に設定したキャリブ レーターによって值付けされており，標準物質という
ものが設定されていない中で，多くの評価がされてき た。 そのため, 方法や試薬間におけるデー夕差異が少 なからず発生し，デー夕統一に向けた標準化の必要性 が出てきた.

Lp (a)測定に関する標準化については，1989 年米 国の CDC (Centers for Disease Control and Prevention）が主催した精度管理調査を機に提起された。 1990 年の AACC 会期時に IFCC (International Federation of Clinical Chemistry) により Lp (a)免疫測 定の標準化に関する提案がされ，1995 年 4 月より IFCC Lp (a) 標準化に関するワーキンググループ (IFCC Working Group on Lp (a), 以下 IFCC Lp (a) WG）として具体的な活動が開始された5).

一方，我が国では 1993 年 12 月に日本臨床病理学会

Standardization for $\operatorname{Lp}(\mathrm{a})$ measurement and clinical investigation.

* Katsuo Kubono ; 株式会社エスアールエル研究検査部

** Katsuo Kubono ; 杏林大学医学部生化学第二

*** Ikunosuke Sakurabayashi ; 自治医科大学大宮医療センター総合医学 I , 検査部 Correspondence address: Katsuo Kubono, SRL, Inc., 153, Komiya-cho, Hachioji, Tokyo 192-0031 Japan. 第 48 回日本電気泳動学会春季大会・シンポジウム 
の標準化委員会の中に「アドホック $\mathrm{Lp}(\mathrm{a})$ 標準小委 員会」(河合忠委員長) が組織され，Lp (a) 測定に関 する実態調査や標準物質統一によるキット間是正に向 けた活動を行ってきたが，現在は IFCC と歩調を合わ せて進めている6).ここでは IFCC Lp(a)WG の標準 化活動を中心に，これまでの検討結果を紹介しながら 標準化の状況報告をする.また，これに伴って Lp (a)の測定意義に対する再評価の可能性についても触 れる.

\section{$\mathbf{L p}(\mathbf{a})$ 測定の標準化}

IFCC Lp (a)WG（委員長は Marburg 大学の Prof. Armin Steinmetz) は，オーストリア・ドイツ・ノル ウェー・フランス・アメリカ・オーストラリア・日本 （櫻林・自治医大）の代表計 7 名からなる委員で構成 されている (表 1).

WG での標準化の手順については第 1 回の会議 (1995 年 4 月, ドイツ) の折りに次の 3 点に絞って行 うことが合意され，これに沿って検討されてきた。

(1) Primary Standardの作成

(2) Reference Material への值の assignment

(3) Reference Material の選択法

\section{Reference Material $の$ 選択}

国内では各試薬に添付されているキャリブレーター は様々であり, その值付けについては各企業の基準に よって実施されているのがほとんどである.ただし， 国内の Lp (a) 測定值は先行試薬の值が目安となって いたためか，各社ほぼ同様な数值となっている，各キ ヤリブレーターの性状やマトリクスは様々であり, 試 薬が異なれば同じキャリブレーターを使用することが できない.そのため試薬とキャリブレーターは対で用 いられるのが常となっている7).

IFCC Lp (a)WG で先に進められた作業は Reference Material の選択である. 新たに Reference Material

表1. IFCC Lp（a）WG の委員一覧.

\section{委員長：Prof. Armin Steinmez}

(St. Nikolaus-Stiftshospital)

\section{委 員:}

Prof. Kare Berg (Univ. of Oslo)

Dr. Remi Couderc (Tenon Hospital)

Prof. Gerhard Kostner (Univ. of Graz)

Dr. Nader Rifai (Children Hospital)

Prof. I. Sakurabayashi (JMC Omiya Med. Center)

Mrs. Jill Tate (Princess Alexandra Hospital)

Dr. Francesco Dati (DADE Behring) : Secretary
を作成するというのでなく，既存の物質から適したも のを選択するという考元方で作業が進められた。すな わち, 各国企業で保有している Reference Material のうち適していると思われるものが提出され，本委員 会が主催した 2 度にわたるサーベイ（世界 35 施設が 参加）が実施された. Linearity, Parallelism, Reproducibility どについて評価がなされ, Commutability, Harmonization を考慮した上で，候補 にあがった $8 つ の$ Proposed Reference Material: PRM 候補品から第一段階で 4 つの候補品（オースト リア，ドイツ，アメリカ，日本）が，次の段階で 2 つ の PRM 候補品（オーストリアとドイツ）が選択され た.

図 1 は第一段階で検討した 4 つの PRM 候補品（そ れぞれ PRM-1，2，3，5）について Lp(a)phenotype を確認したものである. PRM-1のように単一 phenotype のものと他の PRMのように複数の phenotype を含むものがある.PRM として選定する には，できるだけ人血清に近い組成が望ましいと考え られた。

様々な角度から評価と討議を重ね，今年の夏に最終 的な 1 種の PRM の絞り込みがされ, PRM-2B：Behring（ドイツ）のものが選択された。
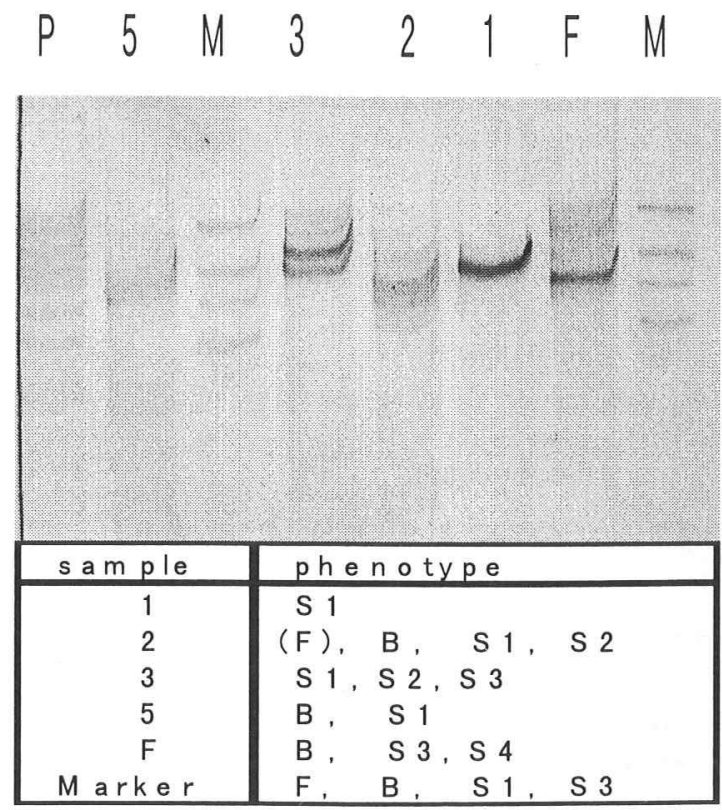

図 1. 各 PRM の $\mathrm{Lp}(\mathrm{a})$ phenotype. 
2. Primary Standard の作成

やや遅れて実施された Primary Standard の作成に ついては，委員の一人である Prof. Kostner（オース トリア・Graz 大学) が単一の phenotype (homozygote, Kringle IV 21-24 程度）を持つ血清から Lp （a）を精製し，蛋白量，アミ八酸分析，各脂質組成等 の分析から $\mathrm{Lp}(\mathrm{a})$ 量を求めることを提案し, 昨年 Prof. Kostner が精製した 2 種類の Primary Standard 候補品を，オーストリア・アメリカおよび日本 において分析・評価を実施した。

Kostnerより送付された $\mathrm{Lp}$ (a)-1，Lp (a) -2 と呼ば れる $2 つ 0$ Primary Std 候補品について, 脂質組成, phenotype，アミノ酸分析などの確認実験を行った。 図 2 はリポ蛋白組成を示したものである。

Lp (a)-2ではベータ位側にテーリングが見られ，生 成段階での変性か, 他の蛋白のコンタミが予想され た。これはのちの Kostner からの報告によるとコン

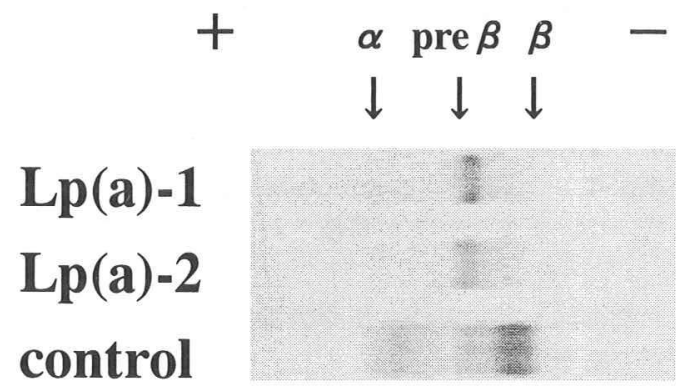

図 2. Primary standard 候補品のリポ蛋白電気泳動.
タミがあったとのことであった。

図 3 は 2 つの Primary Std 候補品のイムノブロッ トである。

SDS-PAGEののちに Western ブロットを行ったと ころ，Kringle IV数でそれぞれ 21 ないし 23 の位置に 単一バンドが確認された。さらにこれら候補品のアミ ノ酸分析を実施した。アミノ酸分析は, 塩酸加水分解 後に日立アミノ酸分析装置 L-8500による分析を実施 した。 なお，加水分解条件が一部アミノ酸に影響を及 ぼすことを想定し，参考までに塩酸加水分解とメタン

\section{Marker Lp(a)1 Lp(a)2}

\section{number of kringleIV}

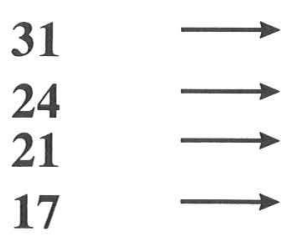

図 3. Primary standard 候補品のイムノブロット.

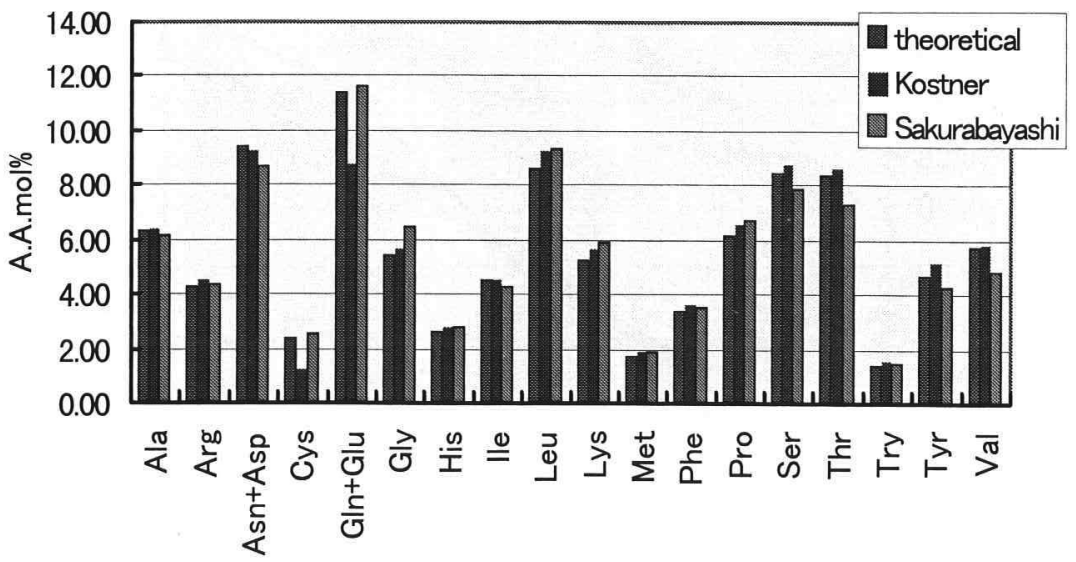

Amino Acids

図 4. Primary standard 候補品のアミノ酸組成比の比較. 
スルフォン酸加水分解を比較したが, 大きな差異は認 められなかった。

Lp (a)のアミノ酸組成が既に明らかにされているの で, 理論的に計算した各アミノ酸組成と我々の実測 値, Kostner らの実測值の比較を図 4 に示した。一部 のアミノ酸組成比に差異はあるものの, ほぼ満足のい く結果であった。

これらの脂質組成の分析やアミノ酸組成の結果か ら, 候補品の $\operatorname{Lp}(\mathrm{a})$ 濃度を算出した. なお $\mathrm{Lp}(\mathrm{a})$ 濃 度の表記方法は mole 表示とすることが合意された。

\section{PRM への值付け}

Primary Std および PRM についての設定作業がほ ぼ終了し，次に Primary Std を用いて PRM に值付 けを行うステップに進んだ。

Reference Methodとして KostnerらはDELFIA 法を推奨しているが, 我々は国内で使用しているいく つかの方法によって検討を実施することとした。我々 が検討したデータの一部を示す。図 5 は Stdに Lp (a)-1 を用いて，PRM を 4 つの方法を用いて測定し たものである。

トクヤマはポリクローナル抗体によるLTIA 法, 第一はモノクローナル抗体による LTIA, ベーリング はポリクローナル抗体によるネフェロメトリー, バイ オプールはポリクローナル抗体による ELISA であ る.バイオプールの系では直線性に問題が生じた。

これらの結果は IFCC に報告しているが，まだ各検 討施設での結果を含めた討議はなされていない.

\section{IFCC $\operatorname{Lp}(a) W G$ の合意内容}

上述のように現在までの IFCC Lp (a) WG 合意事項 をまとめた。

(1) Phase I で 8 候補品全般のデータ比較を実施し た.

(2) Phase II では 4 種に絞られたPRMの具体的な 性能評価比較を実施した。そしてその中から PRM-2 B (Behring 社) を最終的に PRM とし て選択した。

(3) Phase III では Primary Reference Material か ら PRM-2 B への值付けと国際 Harmonization を目指すこととしている。

今後 1 年以内に検討を終了し, WG としての結論 を IFCC から最終的には WHOに答申していくもの と考えられる。

\section{標準化による臨床評価への影響}

Lp (a) は国内では 1993 年 10 月に健康保険の適用を 受けて以来, これまでに多くの臨床の場で測定され, 虚血性心疾患やさまざまな疾患との関連性が評価され てきた。

しかし測定方法・試薬の多様化が先行したために， 各測定キット間での commutability が十分に確認さ れていないままデータが蓄積されてきたのが現状であ る.

標準物質・測定方法・使用機器の互換性などの多く の面で標準化がされるとともに, Lp (a)の臨床的な測

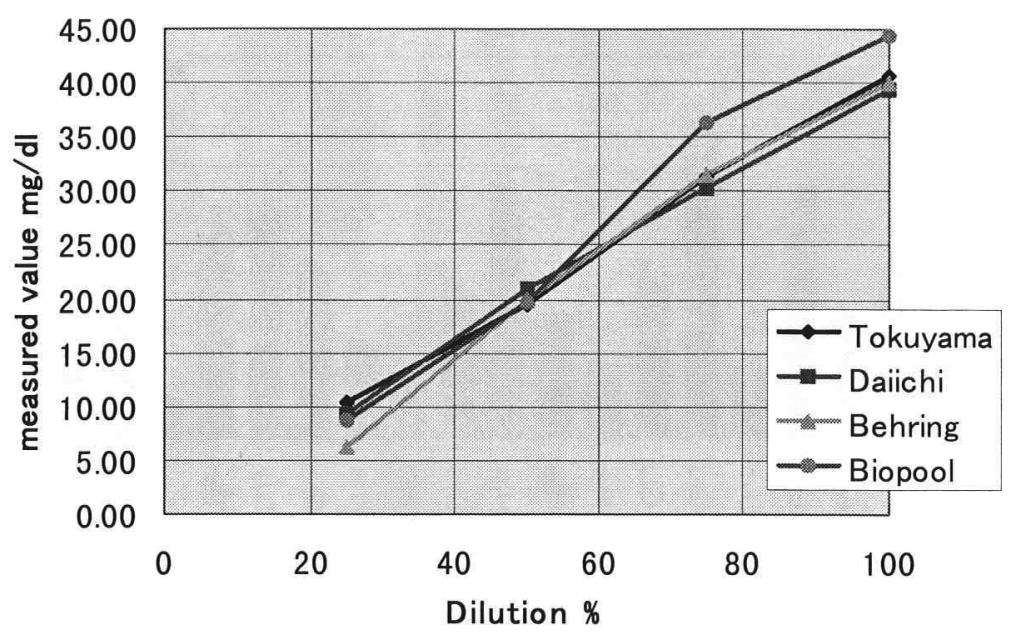

図 5. Primary standard 候補品を用いた PRM への值付け. 
定意義が再評価されるべきであるとの意見も高まりつ つある。

今回の IFCC の標準化作業で Lp (a) Primary Standard, PRM が設定され, 濃度は mole で表現される 方向となった。しかし現在国内では各試薬ごとに值付 けがされており，全てのキットがリポ蛋白の重量濃度 $\mathrm{mg} / \mathrm{dl}$ で表現されている. IFCC 標準化によって生じ る影響について以下に述べてみた。

\section{PRM とキャリブレーターの問題}

アドホック Lp (a) 標準小委員会が実施した国内サ ーベイの結果では，国内で販売されている試薬ごとの 検体における相関性は良好であった。しかし，キャリ ブレーターと試薬は同一キットの組み合わせで使用し なければならず，他の試薬と共用できるキャリブレー ターはない.

今回の IFCC Lp (a)WG で選択された PRM は, ヒ 卜血清ベースで調整されたものであり，おそらく国内 の各試薬に適用しても試薬間差は生じないことと予想 される。しかし, 絶対値はこれまでの国内 $\mathrm{Lp}(\mathrm{a})$ 值 と差異が確認されており，この点では検討が必要とな ってくるであろう。また，標準化システムの中で PRM は二次標準血清の位置づけであり, 実際にルチ ンワークで用いられることは少なく，各試薬を販売す る企業においてキャリブレーターに值付けする際の基 準となることが予測される。したがって，各企業にお けるキャリブレーターはヒト血清ベースで調整された ものとなることが望ましいと考える.

\section{2. mole 表現の影響}

Lp (a)には phenotype が存在し, Kringle 構造 (Kringle IV) の繰り返しが最大 37 個まで存在するこ とから, mole で表現した場合にはリポ蛋白の重量で 捉えた場合に比較して最大 1.5 倍もの差が生じること となる。

我々のデータ（図 6，7）によれば，日本人の Lp (a) phenotype は Utermann らの旧分類で表現すると $\mathrm{S} 4$ タイプが最も多いことがわかっているが，S4タ イプは S 1 タイプの 1.2 倍ほど分子量的に差があるわ けであり, リポ蛋白濃度で表現した場合と mole 表現 した場合とでは数值の持つ意味は大きく変わってくる ことになる。また，国際的に phenotype は, Utermann らの旧分類から Kringle IV数で表現する方向に なりつつあり，この表現で示せば同様に Kringle IV 35 と Kringle IV 21 では約 1.2 倍の数值の差が生じる こととなる.

表 2 は Lp (a) phenotype Kringle IV 数で表示し た場合と国内で主に用いられている旧 Utermann 分 類で表示した場合とを対比させたものである.

国内では ApoB-100 の異動度を基準にして，これよ り異動度の早いものを $\mathrm{F}$, 遅いものを順に S 1 から S 4 までと表現しているが, Immuno 社の標準に比較 すると B タイプでも異動度が異なってしまっている。 Immuno 社の Lp (a) phenotype 標準血清は Kringle IV数に応じた Utermann 表現をも対比させているが, 表に示したように我々の施設あるいは国内市販品の表

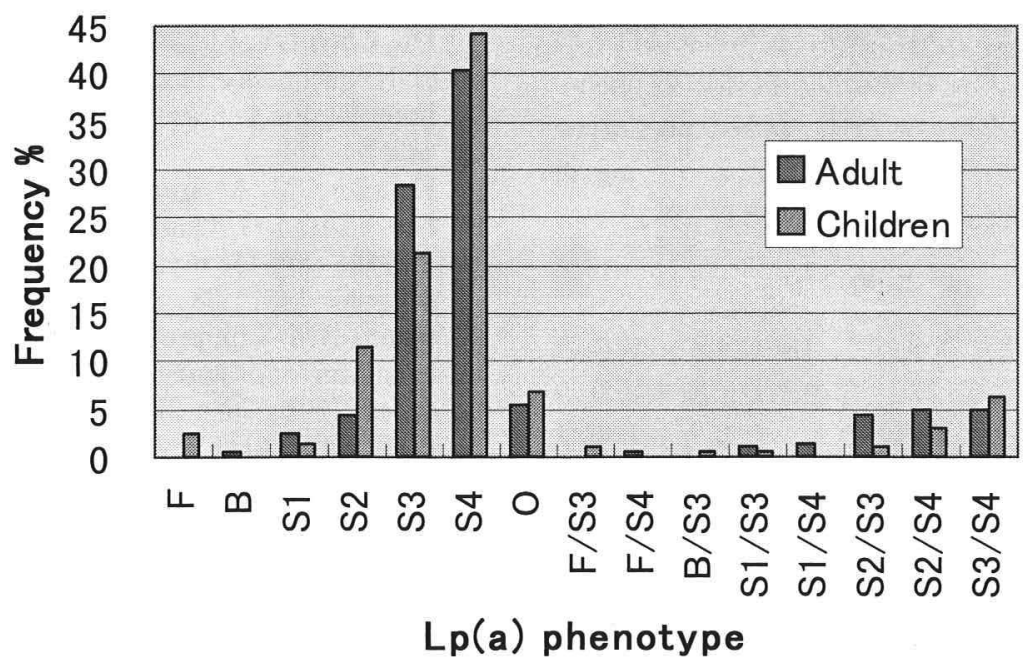

図 6. 日本人の phenotype 頻度. 


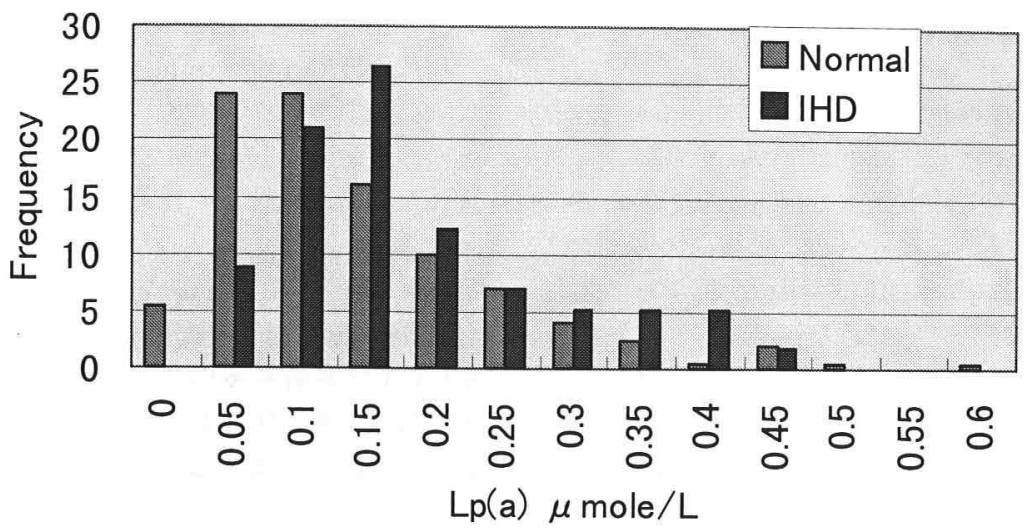

図 7 mole 表現した際の Lp (a) ヒストグラム。

表 2. Kringle IV 数と Utermann 分類の対比表.

\begin{tabular}{cccc}
\hline $\begin{array}{l}\text { Number of } \\
\text { Kringle N } \\
\text { repeats }\end{array}$ & $\begin{array}{l}\text { Nomenclature } \\
\text { according to } \\
\text { Utermann }\end{array}$ & $\begin{array}{l}\text { Nomenclature } \\
\text { according to } \\
\text { Sanwa }\end{array}$ & $\begin{array}{l}\text { Nomenclature } \\
\text { according to } \\
\text { SRL }\end{array}$ \\
\hline 35 & $>$ S 4 & S 4 & S 4 \\
27 & S 4 & S 2 & S 2 \\
23 & S 3 & S 1 & S 1 \\
19 & S 1 & B & B \\
14 & B & & \\
\hline
\end{tabular}

示との間にズレが生じている.すなわち, 旧 Utermann 分類から Kringle IV数への単純变換時には注意 が必要である。

このようなことから，もしも過去の測定值を mole 表示とする場合には, 用いた試薬, 抗体の反応性と検 体の phenotype によって異なり，抗体の各 phenotypeへの反応性の違いのほかに, 試料の phenotype がシングルバンドかダブルバンドかによって $\mathrm{mg} / \mathrm{dl}$ から moleへの変換も異なってくることになる.

\section{まとめ}

Lp (a)測定の標準化について，IFCC Lp (a)WGの 標準化活動を中心に述べた。現在までに標準物質や Reference Materialの設定がされ, 表現方法も重量 表示から mole 表示に変更する提起がされている.

基本的に標準化はデータの統一化というものが期待 できるのだが, Reference Material の各試薬への適 用や $\mathrm{Lp}(\mathrm{a})$ 測定值をこれまでの重量濃度から新たに mole 濃度表示に変えることによって生じる混乱は避 けられないことであろう。標準化は合意であり，決定
された事項について皆ができる限りこれに適するよう 努力することもまた必要なことと考える，Lp（a）には phenotype が存在しており, Lp(a)の作用機序を分子 として捉えるとするならば, mole 表示とすることも 望ましいとも考えられる.

そして今までの臨床的評価に加えて, mole レベル でのデー夕蓄積がされることによって，新たな評価が 得られる可能性を持っており, 標準化以降の今後の臨 床的検討に期待したい。

\section{文献}

1) Berg K. A new serum type system in man-The Lp system. Acta Pathol Microbiol Scand 1963; 59: 369-82.

2) Mclean JW, Tomlinson JE, Kuang WJ, Eaton DL, Chen EY, Fless GM, Scanu AM, Lawn RM. cDNA sequence of human apolipoplotein (a) is homologous to plasminogen. Nature 1987; 300 : 132-7.

3) Kostner GM, Avogaro P, Cazzolato G, Marth E, Bittolo-Bon G, Qunici GB. Lipoprotein Lp(a) and the risk for myocardial infarction. Atherosclerosis $1981 ; 38: 51-61$.

4) Scanu AM. Lipoprotein (a). A genetic risk for premature coronary heart disease. J Am Med Assoc 1992； 267 : 3326-9.

5）国際標準委員会報告 国際化学連合（IFCC） Working Grroup Lp (a). 臨床病理 1996; 44 : 297-8.

6）櫻林郁之介, 細萓茂実, 亀子光明, 高橋 修, 久保野 勝男, 太田抜徳, 山下寿美子, 五十嵐富三男, 戸塚 実, 藤田誠一, 真鍋満久, 清水喜久男, 重松 貴, 山 田晋吾, 高橋良夫, 金子隆司, 久保信彦, 片山善章, 安部 彰, 野間昭夫, 河合 忠. 日本臨床病理学会 
標準委員会・アドホック $\operatorname{Lp}(a)$ 標準小委員会報 告 II. 標準物質統一によるキット間差是正の試 みに関するサーベイ. 臨床病理 $1996 ； 44 ： 292-6$.

7）久保野勝男. 免疫化学的検查における試薬間誤差 の現状と問題点 $-\mathrm{Lp}(\mathrm{a})$-. 臨床化学 1994 ; 23 (補) : 23-7.

\section{要旨}

Lipoprotein (a) [Lp (a) ] 測定に関する標準化につ いては，IFCC の Lp (a) 標準化に関するワーキンググ ループ (IFCC Working Group on Lp(a)) や日本臨 床病理学会標準化委員会のアドホック $\mathrm{Lp}(\mathrm{a})$ 標準小 委員会が活動を行っている。現在までに IFCC Lp(a)
WG では，8 種の Proposed Reference Material 候補 品全般の各種性能評価比較を実施し, その中から PRM-2 B（Behring 社）を最終的な PRM として選 択した.さらに今後は Primary Reference Material から PRM-2 B への值付けと重量表示から mole 表示 への変更を含めた国際的 Harmonization を目指すこ ととしている. 今後 1 年以内に検討を終了し, WG としての結論を IFCC から最終的には WHO に答申 していくものと考えられる. 今までの臨床的評価に加 えて, mole レベルでのデー夕蓄積がされることによ って, 新たな評価が得られる可能性を持っており, 標 準化以降の今後の臨床的検討に期待したい. 